\title{
EKSPLORASI KONSEP MATEMATIKA PADA BATIK JETIS SIDOARJO UNTUK MENTRANSFORMASIKAN KONTEKS PEMBELAJARAN MATEMATIKA DI SEKOLAH DASAR
}

\author{
Silvi Amaliatus Sholihah ${ }^{1}$, Ikamaya Sridarma Dewi ${ }^{2}$, Neni Mariana ${ }^{3}$ \\ ${ }^{1,2,3}$ Universitas Negeri Surabaya
}

\begin{abstract}
The background of this research is based on culture and experiences of the researcher when studying mathematics during became student. As Sidoarjo citizen, researcher never had experienced studying mathematics with local culture. Integration of culture and mathematics known as ethnomathematics. One of cultures in Sidoarjo is batik Jetis. The aim of this research is to exploration mathematics concept in primary school on batik Jetis Sidoarjo. The type of this research is qualitative transformative with writing as inquiry method, postmodern interview, and literature study.The results of this research show that on the steps of the the process batik Jetis Sidoarjo there are some concepts of mathematics. The concepts of the steps berofe production are whole number, the operations of whole number, measurement, and statistics. The concepts of the production process are ordinal number, time, and geometry as straight lines, zig-zag lines, parallel, rotational symmetry, curve, triangle, rhombus, circle, rectangle, oval, fold symmetry, and reflection. Meanwhile, the concepts of after production are measurement, money, and statistic. The results of this research ultimately had an impact on changing views of researcher and teacher who previously thought that culture and mathematics had absolutely not related, changed and understood that culture and mathematics are closly related.
\end{abstract}

Keyword: Batik Jetis Sidoarjo, Ethnomathematics, Transformative

\begin{abstract}
Abstrak: Penelitian ini dilatarbelakangi oleh kultur peneliti dan pengalaman peneliti pada saat belajar matematika selama menjadi siswa. Peneliti sebagai orang Sidoarjo tidak pernah mengalami pembelajaran yang dikaitkan dengan budaya setempat terutama dalam pembelajaran matematika. Keterkaitan budaya dan matematika dikenal dengan istilah etnomatematika. Salah satu budaya yang dimiliki oleh Sidoarjo adalah batik jetis Sidoarjo. Adapun tujuan dari penelitian ini adalah untuk mengeksplorasi konsep matematika di sekolah dasar pada batik Jetis Sidoarjo. Penelitian ini berjenis kualitatif transformatif dengan metode autoetnografi melalui writing as inquiry, wawancara semiterstruktur, dan studi literatur. Hasil eksplorasi menunjukkan bahwa pada tahapan pembuatan batik Jetis Sidoarjo terdapat konsep matematika. Pada tahap persiapan produksi terdapat konsep bilangan cacah, operasi bilangan bulat, satuan baku, dan penyajian data. Pada tahap proses produksi terdapat konsep bilangan ordinal, satuan waktu, geometri seperti garis lurus, garis zig-zag, garis sejajar, simetri putar, kurva, segitiga, belah ketupat, lingkaran, persegi panjang, oval, simetri lipat dan pencerminan. Sedangkan pada tahap pasca produksi terdapat konsep satuan panjang, mata uang, dan penyajian data mean, median, modus, grafik, dan tabel. Melalui penelitian ini dapat merubah pandangan dari peneliti dan guru di sekolah dasar yang sebelumnya matematika tidak memiliki hubungan dengan budaya, berubah bahwa matematika dan budaya memiliki kaitan yang erat.
\end{abstract}

Kata Kunci: Batik Jetis Sidoarjo, Etnomatematika, Transformatif

\footnotetext{
' Universitas Negeri Surabaya, Email: slviamalial[19回gmail.com

${ }^{2}$ Universitas Negeri Surabaya, Email: ikamayasridarma

${ }^{3}$ Universitas Negeri Surabaya, Email: nenimariana 国unesa.ac.id
} 


\section{PENDAHULUAN}

Sidoarjo merupakan Kota kelahiran peneliti. Sidoarjo berbatasan dengan beberapa Kota besar lainnya seperti Surabaya, Mojokerto, Pasuruan, dan Gresik. Menurut Badan Pusat Statistika (2016), luas kabupaten Sidoarjo adalah $634,38 \mathrm{~km}^{2}$. Sedangkan jumlah penduduk kabupaten Sidoarjo adalah 2.259.673 jiwa. Meskipun Kota Sidoarjo sudah cukup modern, akan tetapi masyarakatnya tidak meninggalkan budaya atau kearifan lokal yang ada. Menurut (Alwasilah, 2009, hlm. 16), kriteria dari kearifan lokal yaitu: (1) memiliki hubungan dengan keyakinan masyarakat tertentu, (2) dilakukan pada kehidupan dan komunitas masyarakat, (3) mengalami perubahan sesuai dengan perkembangan waktu, (4) tetap dilakukan oleh masyarakat setempat, (5) fleksibel terhadap perkembangan kultur masa kini, (6) didapat berdasarkan pengalaman, (7) dilaksanakan sejak dahulu atau tidak dalam waktu yang singkat. Salah satu budaya atau kearifan lokal tersebut adalah batik Jetis Sidoarjo. Batik ini hanya diproduksi di satu desa yang bernama Jetis atau lebih dikenal dengan kampung batik Jetis Sidoarjo.

Kampung Batik Jetis Sidoarjo terletak di tengah-tengah pusat Kota, tepatnya pada di Jalan Diponegoro, Lemah Putro, Kecamatan Sidoarjo. Kampung ini memiliki banyak pengusaha dan pengerajin batik yang sudah ada sejak tahun 1950. Pada mulanya pengusaha batik Jetis Sidoarjo hanya memproduksi batik tulis, akan tetapi seiring dengan berjalannya waktu saat ini sudah terdapat jenis batik yang lain seperti batik cap dan batik print. Batik tulis Jetis Sidoarjo memiliki motif yang beraneka ragam seperti motif beras utah, motif krubutan (campuran), motif burung merak, dll. Proses pembuatan batik tulis yang masih tradisonal menghasilkan motif yang lebih indah daripada jenis batik yang lain, sehingga permintaan pasar pun jauh lebih ramai. Ciri khas dari batik Jetis Sidoarjo adalah adanya "cecek" atau titik pada setiap motif yang ada. Proses pembuatan hingga motif batik Jetis Sidoarjo sesuai dengan pengetahuan asli masyarakat yang terdapat konsep matematika jika dikaji lebih lanjut.

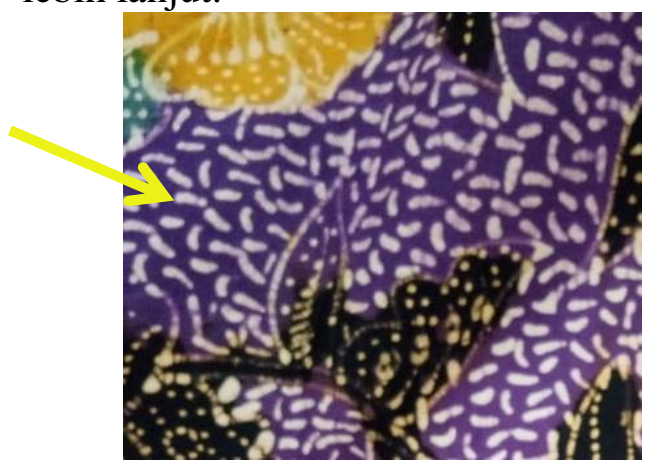

Gambar 1. "Cecek” pada Batik Jetis Sidoarjo

Menurut (Ambrosio, 1985), Konteks matematika yang terdapat dalam budaya disebut dengan etnomatematika. Pembelajaran etnomatematika penting diterapkan di sekolah guna memperkaya konteks matematika itu sendiri dan sebagai sumber belajar bagi peserta didik. Etnomatematika dapat memotivasi peserta didik untuk mengaplikasikan pengetahuan secara kontekstual dan memberikan persepsi keterkaitan antara budaya dan matematika sehingga pengetahuan peserta didik akan lebih bermakna serta menunjang pengetahuan peserta didik terhadap budaya lokal (Rosa et al., 2016). Budaya dan pendidikan merupakan komponen yang saling menyatu dan terkait karena saling melengkapi satu sama lain (Ulum dkk, 2017).

Berdasarkan pengalaman peneliti selama menjadi siswa mulai dari TK hingga SMA, peneliti tidak pernah menemukan pengintegrasian budaya Sidoarjo ke dalam pembelajaran yang ada di sekolah termasuk ke dalam mata pelajaran matematika. Selama ini peneliti menganggap bahwa matematika hanyalah rumus dan angka. Hal tersebut mengakibatkan peneliti kesulitan memahami konsep matematika bahkan mengalami kecemasan (anxiety) karena guru matematika peneliti tidak menggunakan konteks serta aktivitas sehari-hari yang ada di masyarakat 
setempat dalam pembelajaran matematika. Melalui refleksi diri tersebut peneliti bertanya kepada diri sendiri, sebenarnya apa saja budaya yang ada di Sidoarjo? Bukannya Sidoarjo memiliki salah satu budaya yaitu Batik Jetis Sidoarjo? Peneliti berfikir mengapa batik tersebut tidak dijadikan konteks dalam pembelajaran matematika. Menurut Zuliyawati \& Mariana (2019), penggunaan konteks matematika berarti mengenalkan konsep matematika melalui suatu masalah atau situasi tertentu agar pembelajaran menjadi bermakna. Melalui konteks batik Jetis Sidoarjo dalam pembelajaran matematika sehingga siswa tidak hanya memahami materi matematika saja, melainkan juga peduli terhadap kelestarian budaya setempat yang dimiliki.

Berdasarkan uraian diatas peneliti ingin melakukan penelitian dengan judul "Eksplorasi Konsep Matematika pada Batik Jetis Sidoarjo untuk Mentransformasikan Konteks Pembelajaran Matematik di Sekolah Dasar". Adapun rumusan masalah dari penelitian ini adalah (1) Bagaimana konteks matematika SD yang dapat ditemukan serta ditransformasikan berdasarkan pada pengalaman peneliti dan pengerajin batik jetis Sidoarjo?

Bagaimana pandangan guru tentang hasil eksplorasi batik Jetis Sidoarjo sebagai transformasi konteks dalam pembelajaran matematika di Sekolah Dasar?

\section{METODOLOGI PENELITIAN}

Metode yang akan digunakan dalam penelitian ini adalah kualitatif dengan tipe transformatif. Menurut Taylor \& Luitel (2019), tujuan dari penelitian transformatif adalah untuk menyiapkan guru di era revolusi industri dalam mengembangkan kebijakan pendidikan dan praktis pedagogis berdasarkan budaya lokal dan lingkungan alam. Penelitian ini menggabungkan beberapa paradigma baru (multiparadigmatic) yaitu paradigma interpretasi, paradigma kritis, dan paradigma postmodern. Ketiga paradigma tersebut memiliki implikasi yang berbeda dalam penelitian.

Implikasi dari pradigma interpretasi adalah peneliti dapat menjadi data penelitian untuk menginterpretasi hasil eksplorasi konsep matematika pada batik Jetis Sidoarjo melalui refleksi diri. Paradigma kritis dalam penelitian ini berguna untuk mendorong peneliti untuk berfikir suatu perubahan praktik pedagogis dalam pembelajaran matematika yang lebih baik. Sedangkan implikasi dari paradigma postmodern yaitu gaya penulisan yang lebih bebas karena cerita, gambar, atau puisi dapat digunakan sebagai data penelitian (Taylor \& Medina, 2013).

Dalam penelitian transformatif tidak ada prosedur baku yang dapat digunakan. Akan tetapi, terdapat dari lima dimensi dari Taylor yang dapat digunakan yaitu Cultural Self Knowing, Relational Knowing, Critical Knowing, Visionary and Ethical Knowing, serta Knowing in Action. Kelima dimensi tersebut digunakan untuk meningkatkan kesadaran, perhatian, serta bertujuan untuk mendorong peneliti agar menjadi lebih baik dari sebelumnya.

Langkah pertama dari penelitian ini menggunakan dimensi Cultural Self Knowing serta Visionary and Ethical Knowing melalui autoetnografi dengan merefleksi kultural diri peneliti. Refleksi diri dilakukan melalui pengalaman peneliti bahwa pada saat pembelajaran matematika guru tidak penah mengintegrasikan budaya dan matematika. Peneliti berfikir di era globalisasi seperti ini pengintegrasian budaya dalam pembelajaran penting dilakukan agar generasi muda peduli terhadap budaya setempat yang dimiliki. Langkah kedua yaitu dengan menggunakan dimensi Relational Knowing dan Cultural Self Knowing melalui studi literatur dan wawancara. Studi literatur, autoetnografi dan wawancara kepada pengerajin batik Jetis Sidoarjo akan menghasilkan eksplorasi konsep matematika yang ada pada batik. Kemudian hasil tersebut dikenalkan dan 
ditanyakan melalui wawancara kepada guru bagaimana pandangan mereka tentang hasil eksplorasi yang telah ditemukan. Langkah selanjutnya menggunakan dimensi Critical Knowing dan Cultural Self Knowing sebagai analisis data. Peneliti akan mendeskripsikan dan menginterpretasi konsep-konsep Matematika yang ada pada batik Jetis Sidoarjo yang sesuai dengan kurikulum di Sekolah Dasar. Analisis dilakukan berdasarkan hasil studi autoetnografi, studi literatur, dan wawancara. Langkah terakhir menggunakan dimensi Knowing in Action dengan tujuan membuat kesimpulan. Setelah melakukan eksplorasi, peneliti memiliki visi untuk melakukan praktik pedagogis menjadi lebih baik dalam pembelajaran matematika.

Penelitian ini juga menggunakan pendekatan auto|etnografi. Simbol "|" digunakan sebagai tanda adanya integrasi antara autografi dan etnografi dalam waktu yang sama pada penelitian. Menurut Hardiansyah (2014), etnografi merupakan suatu penelitian yang berkaitan tentang penjelasan desktiptif dan interpretatif pada masyarakat atau suatu kelompok tentang kebudayaan atau tingkah laku yang dilakukan secara langsung. Setelah peneliti melakukan autoetnografi dan mewawancarai pengerajin batik Jetis Sidoarjo, peneliti akan terjun ke sekolah untuk mengetahui pandangan guru-guru di sekolah dasar tentang hasil eksplorasi konsep matematika pada batik Jetis Sidoarjo.

Teknik pengumpulan data dalam penelitian ini menggunakan tiga metode yaitu, studi autoetnografi, studi literatur, dan wawancara. Saat melakukan studi autoetnografi dan literatur, peneliti akan menggunakan pedoman konsep-konsep matematika yang akan dieksplorasi pada batik Jetis Sidoarjo. Hal tersebut bertujuan agar hasil eksplorasi batik Jetis Sidoarjo yang akan dijadikan konteks dalam pembelajaran matematika di sekolah dasar relevan dengan kurikulum saat ini. Di sisi lain, peneliti akan mewawancarai pengerajin batik Jetis Sidoarjo terkait tentang proses, motif, hingga nilai filosofis pada batik tersebut. Setelah itu, peneliti akan terjun ke sekolah untuk mengetahui bagaimana pandangan guru di sekolah dasar terkait hasil eksplorasi konsep matematika pada batik Jetis Sidoarjo.

Teknik analisis data dalam penelitian ini menggunakan model Miles dan Huberman yang terdiri dari reduksi data, penyajian data, serta kesimpulan atau verifikasi (Sugiyono, 2014, hlm. 244). Berikut ini langkah-langkah dalam penelitian ini.

Reduksi data merupakan memilah, memilih, memfokuskan, dan merangkum pada hal-hal yang penting. Jadi, langkah yang dilakukan dalam aktivitas reduksi data adalah mengeksplorasi konsep matematika pada batik Jetis Sidoarjo yang di sesuaikan dengan kompentensi di sekolah dasar. Selain itu, aktivitas reduksi data yang lain adalah memilih cerita pengalaman-pengalaman peneliti yang menjadi fokus penelitian. Peneliti memilih pengalaman terkait pembelajaran matematika yang tidak pernah diintegrasikan dengan budaya di daerah Sidoarjo untuk dijadikan data. Pemilihan tersebut didasarkan pada interpretasi peneliti yang didukung oleh studi literatur.

Langkah selanjutnya adalah menyajikan data. Dalam penelitian transformatif, data akan disajikan dalam bentuk cerita narasi, puisi, dan gambar untuk membantu mengilustrasikan pengalaman peneliti. Hal ini sesuai dengan paradigma postmodern dimana gaya penulisan dalam penelitian lebih bebas sehingga peneliti dapat lebih ekspresif dalam menyajikan data.

Langkah terakhir dalam penelitian ini adalah menyimpulkan/memverikasi data. Kesimpulan data berupa temuan gambaran atau deskripsi suatu objek yang sebelumnya belum jelas menjadi lebih jelas, atau dapat berupa hubungan interaktif atau kausal, hipotesis atau teori. Dalam penelitian ini, peneliti akan menginterpretasikan eskplorasi konsep 
matematika pada batik Jetis Sidoarjo berdasarkan hasil wawancara dengan pengerajin batik dan studi literatur yang relevan. Dengan demikian, hasil interpretasi data tidak hanya penafsiran peneliti semata.

\section{HASIL PENELITIAN DAN PEMBAHASAN}

\section{Sejarah Kampung Batik Jetis Sidoarjo}

Batik Jetis Sidoarjo sudah ada sejak tahun 1675. Pada awalnya, batik ini diajarkan oleh Mbah Mulyadi yang masih memiliki keturunan raja Kediri. Mbah Mulyadi pergi ke Sidoarjo bersama dengan para pengawalnya. Ketika tiba di Sidoarjo, Mbah Mulyadi mengawali berdagang di Pasar Kaget yang kini lebih dikenal Pasar Jetis. Seiring dengan berkembangnya waktu, pasar Jetis semakin ramai dan banyak didatangi oleh para pedagang dari luar Kota yang didominasi oleh pedagang Madura.

Para pedagang Madura tersebut sangat menyukai batik tulis hasil karya warga Jetis. Akan tetapi, perkembangan batik Jetis Sidoarjo sempat terhenti dikarenakan generasi pada saat itu tidak ada yang peduli terhadap perkembangan usaha tersebut. Pada tahun 1950, usaha batik Jetis Sidoarjo kembali didirikan oleh $\mathrm{Bu}$ Widiarsih. Batik tulis $\mathrm{Bu}$ Widiarsih pada saat itu menjadi perusahaan terbesar sekaligus menjadi usaha batik tertua di kampung Jetis.

Pada tahun 1970-an mulai berdiri usaha rumahan batik Jetis tulis yang didirikan oleh para mantan pekerja Widiarsih. Hal tersebut melatarbelakangi batik tulis Jetis menjadi usaha rumahan dan menjadi mata pencaharian utama masyarakat setempat hingga saat ini.

\section{Motif Batik Jetis Sidoarjo}

Batik Jetis Sidoarjo memiliki beberapa motif seperti motif beras Utah, motif burung merak, motif burung merak, dll. Setiap motif batik Jetis memiliki ciri khas yang sama yaitu adanya "cecak" atau titik. Proses pembuatan batik Jetis Sidoarjo memerlukan waktu 1-3 minggu. Hal tersebut sesuai dengan tingkat kesulitan motif yang dibuat.

Pada penelitian ini, peneliti memilih motif beras Utah untuk dieksplorasi lebih dalam terkait konsep matematika yang ada di dalamnya. Motif beras Utah ini menggambarkan hasil bumi terutama padi yang ada pada daerah Sidoarjo. Motif beras Utah disajikan dengan serasi antara objek flora dan fauna dengan isen-isen beras atau cecak (titik). Motif beras Utah ini merupakan salah satu batik Jetis yang banyak dinikmati oleh konsumen.

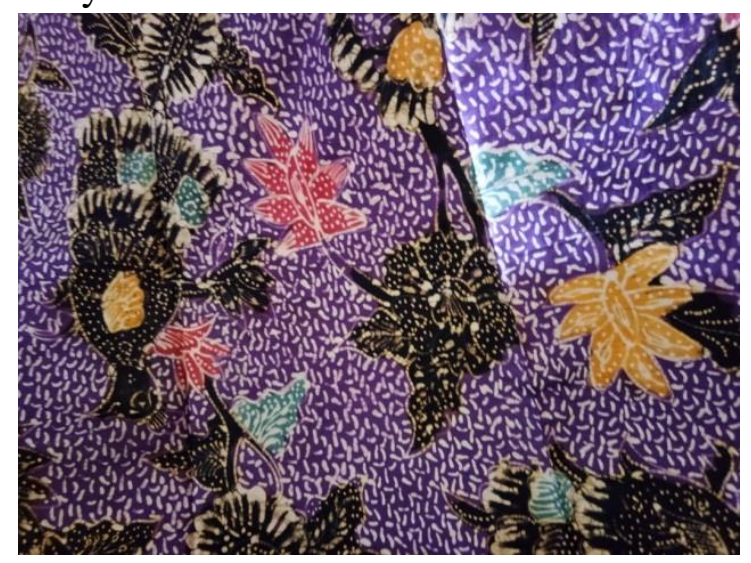

Gambar 2. Motif beras utah pada batik Jetis Sidoarjo

\section{Konsep Matematika pada Batik Jetis} Sidoarjo

Melalui studi autoetnografi, peneliti menggali data diri peneliti yang memungkinkan peneliti sebagai sumber data. Studi autoetnografi didapat berdasarkan cerita pengalaman peneliti yang berhubungan dengan batik Jetis Sidoarjo. Di sisi lain, peneliti melakukan studi autoetnografi diluar pengalaman peneliti dengan mewawancarai pengerajin batik. Hal tersebut bertujuan untuk menjawab rumusan masalah pertama.

Dalam studi autoetnografi, peneliti mengangkat tentang pengalaman masa lalu peneliti yang berhubungan dengan penelitian ini. Ketika peneliti duduk di kelas VI sekolah dasar, peneliti pergi ke Kota Sidoarjo pusat. Peneliti melihat ada tulisan kampung Batik Jetis Sidoarjo. Ayah peneliti memutuskan untuk berhenti sejenak disana. Ayah peneliti membeli empat potong kain batik Jetis. Masing- 
masing potong kain seharga Rp 200.000 dengan ukuran dua meter. Ayah peneliti membayar harga kain batik Jetis tersebut seharga $\mathrm{Rp}$ 800.000. Dari pengalaman tersebut, peneliti menyadari bahwa dalam transaksi jual beli batik Jetis Sidoarjo terdapat konsep mata uang.

Peneliti juga melakukan studi autoetnografi diluar diri peneliti dengan mewawancarai pengerajin batik Jetis Sidoarjo terkait proses pembuatan dan motif yang ada yang bernama Ibu Yat dan Ibu Saripah, serta pemilik usaha bernama Pak Ishaq. Peneliti akan mengeksplorasi konsep matematika pada tahap pembuatan batik Jetis Sidoarjo. Adapun tahap-tahap tersebut adalah persiapan produksi, proses pembuatan batik dan motif, serta pasca produksi.

\section{Persiapan Produksi Batik Jetis Sidoarjo}

Pada saat produksi, pengerajin menyiapkan alat dan bahan untuk membatik. Adapun alat yang digunakan antara lain (1) canting, (2) wajan, (3) kompor, (4) pensil/spidol, (5) gawangan, (6) kuas, (7) bak celup, (8) kursi kecil, dan (9) penggaris. Sedangkan bahan malam, kain, dan pewarna alami. Malam yang digunakan terdiri dari beberapa jenis yaitu damar, getuk, dan malam solo. Begitu pula dengan kain yang digunakan terdiri dari beberapa macam antara lain satung, katun, prima, sutra, kaos, primis, dan sutra. Sedangkan warna yang digunakan terdiri atas warna alami yang berasal dari pohon nangka, pohon manga, pohon jati, pohon nangka, dll, serta pewarna sintetis seperti indigosol, remasol, dan naptol.

\section{Proses Produksi Batik Jetis Sidoarjo}

Batik Jetis Sidoarjo memiliki motif utama flora dan fauna, serta memiliki motif latar dan isi berupa cecek (titik), rawaran (garis yang berjajar), dan lonjongan (lengkung, oval, bulat). Adapun motif yang terkenal pada batik Jetis Sidoarjo yaitu beras utah, krubutan, kembang bayam, dll. Sedangkan warna batik Jetis Sidoarjo terdiri warna utama seperti merah tua, hitam, dan biru tua, serta warna latar seperti cokelat, putih, hijau, dan hitam. Warna tersebut terbuat dari pencampuran bahan alami dan bahan buatan.

Pada saat membatik, pengerajin memperkirakan bentuk motif yang akan dibuat. Misalnya, apabila motif yang akan dibuat berupa burung merak maka burung tersebut memiliki dua kaki, sayap yang lebar, dan ekor. Jika pengerajin akan menggambar bunga maka bentuk kelopaknya adalah oval, saling tumpang tindih (bertumpuk) ataupun tidak. Sedangkan ketika menggambar daun, pengerajin membayangkan bentuknya yang segitiga atau melengkung. Ciri khusus dari batik Jetis adalah adanya cecek (titik) pada setiap batik. Pengerajin tidak membuat jarak pasti antar cecek (titik), akan tetapi hanya diperkirakan. Pengerajin juga tidak menghitung jumlah cecek (titik) dan objek yang dibuat pada setiap batik. Berdasarkan uraian tersebut, dapat diketahui pengerajin memiliki pemikiran yang matematis saat menggambar objek batik Jetis Sidoarjo. Meskipun pemikiran tersebut tidak secara mendetail.

Proses pembuatan batik Jetis Sidoarjo terdiri dari beberapa tahapan yang harus dilakukan secara berurutan. Adapun tahapan-tahapan tersebut adalah sebagai berikut. Pertama, membuat molani (desain batik); kedua, menebalkan molani menggunakan plastisin cair (dicantangi); ketiga, menutupi bagian putih kain menggunakan lilin; keempat, proses pewarnaan pertama bagian yang tidak tertutup oleh lilin; kelima, melukis kembali kain menggunakan canting, dilanjutkan pewarnaan kedua; keenam, mencelupkan kain pada air yang sudah dipanaskan di atas tungku; ketujuh, setelah kain bersih dari lilin, mengulangi proses membatik menggunakan lilin; kedelapan, merebus kain yang berubah warnanya menggunakan air panas (nglorot). Proses ini membutuhkan waktu 5-10 menit; kesembilan, mencuci dan menjemur kain batik sampai kering. Proses ini paling cepat membutuhkan waktu 3-4 jam bergantung pada kondisi cuaca yang ada. 
Keseluruhan proses tersebut membutuhkan waktu 1- 3 minggu tergangantung pada kesulitan motif yang akan dibuat.

\section{Pasca Produksi}

Berdasarkan hasil wawancara dengan Pak Ishaq salah satu pemilik usaha batik Jetis Sidoarjo, setelah semua proses selesai, batik akan dipasarkan ke berbagai daerah di Indonesia. Batik akan dijual dengan ukuran potongan, dimana satu potong terdiri dari dua meter dengan harga sekitar Rp 250.000 - Rp 2.500.000. Pak Ishaq memberikan upah kepada pengerajin batik Rp 100.000 setiap satu potong kain.

Adapun konsep matematika yang ditemukan pada tahapan produksi batik Jetis Sidoarjo adalah sebagai berikut.

\section{Persiapan Produksi Batik Jetis Sidoarjo}

Konsep matematika yang ditemukan pada tahap ini antara lain:

1. Bilangan Cacah

Pada saat menyiapkan alat untuk membatik, terdapat konsep bilangan yaitu menghitung dengan menggunakan bilangan cacah. Melalui alat membatik, siswa dapat menghitung dengan benda konkret. Di sisi lain konsep bilangan juga terdapat pada saat menghitung bahan membatik berupa jenis kain dan warna yang digunakan.

\section{Operasi Bilangan Bulat}

Pada saat menghitung jumlah alat, jenis kain, dan warna yang digunakan untuk membatik terdapat konsep penjumlahan di dalamnya.

3. Satuan Baku

Satuan baku digunakan untuk mengukur kain untuk membatik dengan satuan mater. Sedangkan satuan cairan pada warna batik dapat berupa milliliter atau liter.

4. Penyajian Data

Penyajian data dapat berupa daftar tabel berisi nama alat dan bahan berdasarkan jumlah yang ada.

\section{Proses Produksi Batik Jetis Sidoarjo}

Adapun konsep matematika yang ditemukan pada tahap ini antara lain:

1. Bilangan Ordinal

Bilangan ordinal merupakan bilangan yang menunjukkan tingkatan, urutan, atau tahapan. Pada proses membatik, bilangan ordinal disaat menyebutkan proses yang dilakukan secara berurutan. Misalnya, pertama, kedua, dll.

2. Satuan Waktu

Konsep satuan waktu terdapat pada saat pengerajin merebus kain hingga berubah warnanya atau ngelorot. Proses tersebut membutuhkan 5-10 menit. Konsep satu waktu juga terdapat pada saat mencuci dan menjemur kain batik hingga kering yang membutuhkan waktu 3-4 jam. Di sisi lain, konsep waktu juga terdapat pada estimasi keseluruhan membuat batik yaitu 1-3 minggu tergantung pada kesulitan motif yang akan dibuat.

3. Geometri dan Pengukuran

Berdasarkan pengamatan peneliti dan data wawancara dengan pengerajin batik, pada motif batik Jetis Sidoarjo terdapat konsep geometri dan pengukuran. Konsep tersebut sudah terlihat ketika pengerajin mulai membuat molani (desain batik). Adapun konsep-konsep geometri tersebut dapat dipaparkan sebagai berikut.

Garis lurus, simetri putar, dan pencerminan

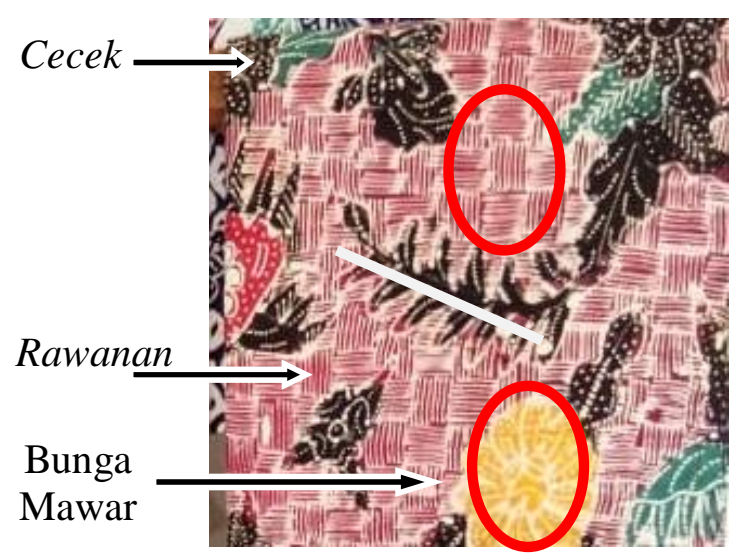

Gambar 3. Batik Jetis Sidoarjo pada motif utama; bunga mawar, motif latar; rawanan, dan motif isen; cecek 
Garis zig-zag, kurva, segitiga, dan belah ketupat

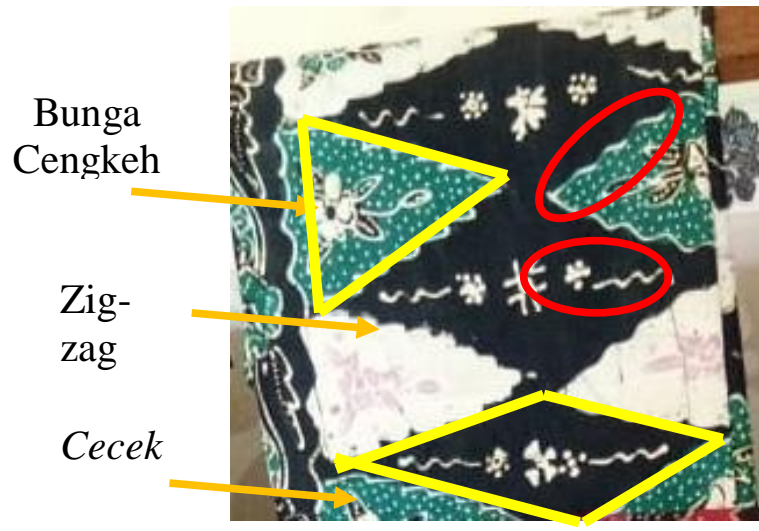

Gambar 4. Batik Jetis Sidoarjo pada motif utama; bunga cengkeh, motif latar; zig-zag, dan motif isen; cecek

\section{Lingkaran dan simetri putar}

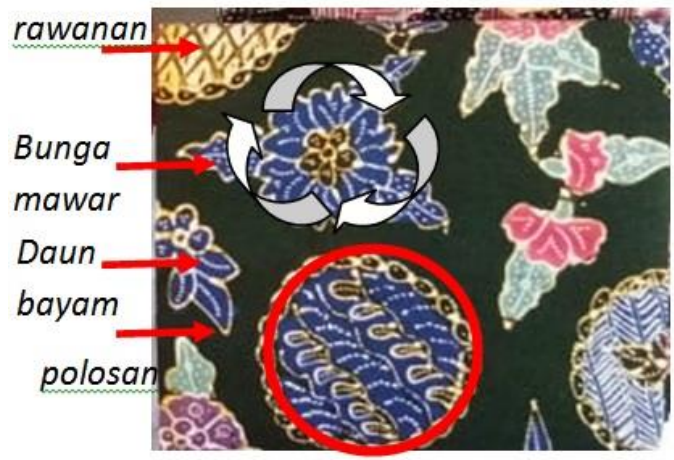

Gambar 5. Batik Jetis Sidoarjo pada motif utama; bunga mawar dan daun bayam, motif latar; polosan, dan motif isen; rawanan

Garis sejajar, persegi panjang, kurva, refleksi (pencerminan)

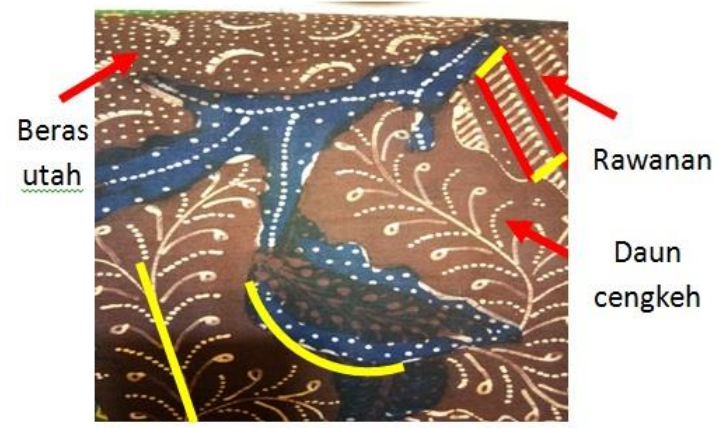

Gambar 6. Batik Jetis Sidoarjo pada motif utama; bunga cengkeh, motif latar; beras utah, motif isen; rawanan
Segitiga, pencerminan, belah ketupat, dan kurva

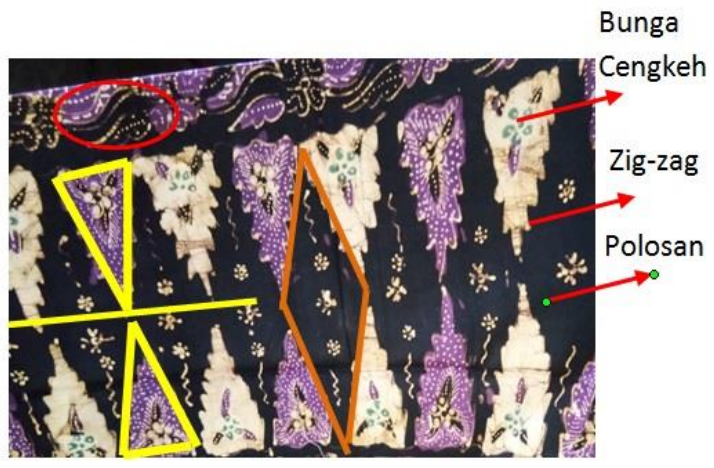

Gambar 7. Batik Jetis Sidoarjo pada motif utama; bunga cengkeh, motif latar; zig-zag dan polosan

Oval, pencerminan, simetri putar, dan simetri lipat

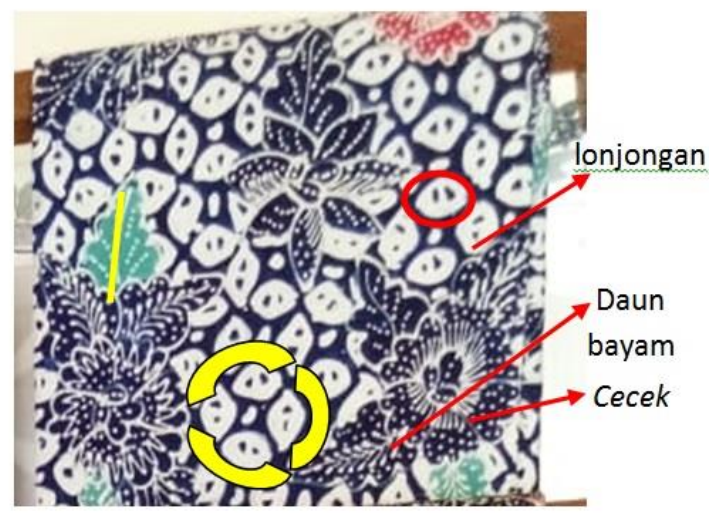

Gambar 8. Batik Jetis Sidoarjo pada motif utama; bunga cengkeh, motif latar; zig-zag dan polosan

\section{Pasca Produksi}

1. Satuan Panjang

Setalah proses produksi selesai, pemiliki usaha batik Jetis Sidoarjo akan memasarkan ke berbagai wilayah di Indonesia dengan ukuran potongan. Satu potong kain batik Jetis berukuran 2 meter. Ukuran tersebut dapat diubah menjadi satuan panjang yang lain.

\section{Mata uang}

Konsep mata uang terdapat pada penjualan batik Jetis Sidoarjo. Konsep mata uang ini ditemukan juga pada cerita autoetnografi peneliti. Satu potong kain batik Jetis yang berukuran 2 meter dijual dengan harga $\mathrm{Rp} 250.00$ hingga $\mathrm{Rp}$ 2.500.000. Hal tersebut tergantung pada 
jenis kain dan motif yang ada. Di sisi lain, konsep mata uang juga terdapat pada upah pengerajin dimana jika pengerajin menyelesaikan satu potong akan mendapatkan upah sebesar Rp 100.000.

\section{Penyajian Data}

Konsep penyajian berupa grafik, tabel, mean, median dan modus. Grafik dapat digunakan untuk mengetahui keuntungan atau kerugian yang didapatkan dalam bulan atau tahun. Tabel dapat digunakan untuk mendata berapa banyak potong kain batik Jetis yang dihasilkan oleh pengerajin dalam satu bulan atau satu tahun. Mean atau rata-rata digunakan untuk mengetahui seberapa banyak pendapatan yang dihasilkan oleh penjualan dan pengerajin batik dalam satu bulan. Sedangkan modus untuk mengetahui motif batik Jetis yang paling diminati oleh pembeli. Selain itu, terdapat juga median untuk mengetahui nilai tengah dari data yang telah disajikan.

Hasil temuan konsep pada penelitian ini cocok digunakan pada pembelajaran matematika di sekolah dasar. Hal ini dikarenkan pembelajaran matematika di sekolah dasar merupakan tahap penanaman dan pengenalan konsep matematika yang paling sederhana. Di sisi lain, pembelajaran matematika di sekolah dasar lebih menekankan pada aktivitas yang dilakukan oleh siswa daripada ceramah Heruman (2012). Penelitian ini cocok diterapkan pada pembelajaran di sekolah dasar karena melibatkan konteks dari budaya yang ada di lingkungan siswa.

Setelah peneliti menemukan konsepkonsep matematika pada batik Jetis Sidoarjo, peneliti mewawancarai guru di SDN 1 Grogol, Sidoarjo. Tujuannya adalah untuk mengetahui apakah guru pernah mengintegrasikan pembelajaran matematika dengan budaya Sidoarjo, serta untuk mengetahui pandangannya terkait konsep matematika yang telah ditemukan. Berdasarkan hasil wawancara, guru mengaku tidak pernah melakukan pengintegrasian pembelajaran matematika dengan budaya Sidoarjo. Hal ini dikarenakan guru menganggap bahwa matematika adalah pembelajaran teoritis sehingga tidak diperlukan adanya konteks. Melalui hasil penelitian ini, guru menemukan referensi untuk melakukan pengintegrasian tersebut.

\section{KESIMPULAN}

Terdapat konsep Matematika dalam batik Jetis Sidoarjo yang dieksplorasi melalui pengalaman masa lalu peneliti, pengalaman peneliti dengan pengerajin batik Jetis, serta studi literatur. Konsep matematika yang ditemukan antara lain pada tahap persiapan produksi; bilangan cacah, operasi bilangan bulat, satuan baku, dan penyajian data. Pada tahap proses produksi terdapat konsep bilangan ordinal, satuan waktu, geometri seperti garis lurus, garis zig-zag, garis sejajar, kurva, segitiga, belah ketupat, lingkaran, persegi panjang, oval, simetri putar, simetri lipat dan pencerminan. Sedangkan pada tahap pasca produksi terdapat konsep satuan panjang, mata uang, dan penyajian data mean, median, modus, grafik, dan tabel. Penemuan konsep tersebut dapat digunakan sebagai alternatif konteks etnomatematika dalam pembelajaran matematika.

Berdasarkan hasil wawancara dengan guru di SDN 1 Grogol menunjukkan bahwa hasil eksplorasi ini dapat digunakan sebagai inovasi terkait dengan budaya dan pembelajaran matematika. Sebelumnya peneliti, partisipan, dan pembaca menganggap bahwa matematika tidak dapat dikaitkan dengan budaya. Namun setelah adanya penelitian ini, peneliti, partisipan, dan pembaca dapat merubah pandangan tersebut bahwa matematika merupakan sebuah aktivitas yang dekat dengan kehidupan sehari-hari termasuk ke dalam budaya. Hasil temuan ini juga diharapkan mampu untuk meningkatkan kesadaran peneliti, partisipan, dan pembaca untuk lebih peduli dan mencintai budaya lokalnya. Di sisi lain, temuan penelitian ini dapat diaplisikan dalam pembelajaran matematika di sekolah dasar 
untuk mencapai kompetensi dasar yang sesuai dengan kurikulum di Indonesia.

\section{DAFTAR PUSTAKA}

Alwasilah, A. C. dkk. (2009). Etnopedagogi Landasan Praktek Pendidikan Dan Pendidikan Guru. Kiblat Buku Utama.

Ambrosio, U. D. (1985). Ethnomathematics and its Place in the History and Pedagogy of Mathematics. 1(February), 44-47.

Hardiansyah, Haris. (2014). Metodologi Penelitian Kualitatif untuk Ilmu Psikologi. Salemba Humanika.

Heruman. (2012). Model Pembelajaran Matematika di Sekolah Dasar. Remaja Rosdakarya.

Rosa, D., Orey, D. C. (2016). Ethnomodelling as a Creative Insubordination Approach in Mathematics Education. 10, 111-134.

Statistik, B. P. (2016). Indeks Pembangunan Manusia 2016. Jakarta (ID): Badan Pusat Statistik.

Sugiyono. (2014). Metode Penelitian Pendidikan Pendekatan Kuantitatif, Kualitatif, dan R\&D. Bandung: Alfabeta.

Taylor, P. C., \& Luitel, B. C. (2019). 1 . Introduction: Research as Transformative Learning for Sustainable Future. Research as Transformative Learning for Sustainable Future, 7, 1-6. https://doi.org/10.1163/97890043933 49

Taylor, P.C., dan Medina, M.N.D. 2013. "Educational research paradigms: From positivism to multiparadigmatic". Journal for Meaning-Centered Education, 1.

Ulum, B., Budiarto, M.T., dan Ekawati, R. 2017. "Etnomatematika Pasuruan: Eksplorasi Geometri Untuk Sekolah Dasar Pada Motif Batik Pasedahan Suropati”. Prosiding Seminar Nasional Integrasi Matematika dan Nilai-Nilai Islami. Vol 1 No 1
Zuliyawati, M. E., \& Mariana, N. (2019). Eksplorasi Konsep Matematika untuk Mentransformasi Konteks Matematika SD yang Mengandung NIlai-Nilai Karakter. Jurnal Penelitian Pendidikan Guru Sekolah Dasar, 7(6). 